\title{
DIALLEL ANALYSIS OF MAIZE RESISTANCE TO Phaeosphaeria maydis
}

\author{
Herberte Pereira da Silva ${ }^{1 *}$; José Roberto Moro² \\ ${ }^{I}$ Syngenta Seeds Ltda., Rod. Washington Luis s/n, km 297 - 15990-000 - Matão, SP - Brasil. \\ ${ }^{2}$ UNESP/FCAV - Depto. de Biologia Aplicada, Via de Acesso Prof. Paulo Donato Castellani, s/n, km 05 - 14884-900 - \\ Jaboticabal, SP - Brasil. \\ *Corresponding author <hpdasilva@uol.com.br>
}

\begin{abstract}
In breeding programs directed towards genetic resistance against diseases, the estimation of genetic parameters that control resistance allows the introduction of resistance into suscetible germplasm to be clearly focused. The purposes of this study were to estimate heterosis effects, and the general (GCA) and specific (SCA) combining abilities by using two rating methods for resistance to Phaeosphaeria maydis in a diallel analysis of $36 \mathrm{~F}_{1}$ maize hybrids and their nine inbred lines. Trials were conducted in three environments. Disease severity was evaluated in the whole plant (PI) and in the leaf positioned just below the point of insertion of the main ear (AFA). The trials followed a randomized block design with plots represented by a $5 \mathrm{~m}$ long rows. Differences among combining ability estimates for different environments and in both evaluation methods showed significant effects $(P<0.01)$ for environment $(\mathrm{E}), \mathrm{GCA}$, and GCA $\times \mathrm{E}$. The SCA, and SCA $\times \mathrm{E}$ effects were not significant for any of the disease severity variables. The GCA effects were more important than SCA for this set of inbred lines, suggesting that additive genetic effects are the most important sources of variation for this trait. Heterosis effects for resistance were estimated, and it was possible to identify specific hybrid combinations between lines which have high potential for genetic control of this pathogen. Results for both disease severity variables were practically identical, even though the PI method was more convenient to use. Key words: Zea mays L., genetic resistance, heterotic effects, general and specific combining ability
\end{abstract}

\section{ANÁLISE DIALÉLICA DA RESISTÊNCIA A Phaeosphaeria maydis EM MILHO}

\begin{abstract}
RESUMO: Em programas de melhoramento visando resistência genética a doenças, a estimativa de parâmetros genéticos que governam a resistência permite direcionar a introdução de resistência em germoplasmas. O objetivo deste trabalho foi estimar os efeitos heteróticos, a capacidade geral (CGC) e específica (CEC) de combinação, utilizando-se de dois métodos de avaliação da resistência, à Phaeosphaeria maydis através da análise dialélica de 36 híbridos $\mathrm{F}_{1}$ e de suas nove linhagens genitoras, em experimentos conduzidos em três ambientes. Foi utilizado um delineamento experimental em blocos casualizados com três repetições e a parcela experimental foi representada por uma fileira de $5 \mathrm{~m}$. As diferenças entre as estimativas da capacidade de combinação, em diferentes ambientes e para os dois métodos de avaliação, apresentaram efeitos significativos $(P<0.01)$ para ambientes (E), CGC e CGC x E. O efeito de CEC e a interação CEC x E não foi significativa para os dois métodos de avaliação. Os efeitos de CGC foram mais importantes que CEC nesse conjunto de linhagens, sugerindo que efeitos genéticos aditivos são mais importantes como fonte de variação para resistência a esta doença. Efeitos heteróticos para resistência foram estimados, sendo possível identificar combinações híbridas específicas entre linhagens com alto potencial para o controle genético deste patógeno. Resultados para os dois métodos de avaliação foram praticamente idênticos, embora o método PI seja de maior praticidade de uso.

Palavras-chave: Zea mays L., genética da resistência, efeito heterótico, capacidade geral e específica de combinação
\end{abstract}

\section{INTRODUCTION}

Phaeosphaeria leaf spot, caused by the fungus Phaeosphaeria maydis (Henn.) Rane, Payak \& Renfro (Sphaerulinia maydis = Leptosphaeria zeae-maydis Saccas), anamorphous stage - Phyllosticta sp., is considered the most important maize disease in Brazil, because of both its widespread distribution and the damages it causes to susceptible cultivars. In Brazil, P. maydis has been considered of great importance in recent years in tropical areas with altitudes above $600 \mathrm{~m}$, favorable conditions are prevalent in the states of São Paulo, Minas Gerais and Goiás (Silva, 1997).

Earlier on, P. maydis had not been causing great damage to the crop because it occurred more frequently at the end of the cropping cycle. Currently, it has been observed in plants at phenological stage 7 according to Hanway's scale (1966). 
The first of Koch's postulates with the fungus $P$. maydis was established by Rane et al. (1965). Later, Fantin \& Balmer (1997) managed to reproduce the symptoms. Paccola-Meirelles et al. (1998) performed the isolation of fungi from lesions described as being from $P$. maydis. However, there is a controversy about the identification of the etiological agent of this disease. Later on, Paccola-Meirelles et al. (2001) did not detect the presence of the fungus, by cytological analysis, at the initial stages of the disease. The isolation of the bacterium Pantoea ananas (Erwinia ananas), from lesions supposedly caused by Phaeosphaeria leaf spot, suggest its participation in the initial stage of the disease, and indicates that the fungus is not the primary pathogen of this disease, as originally proposed.

Maize has great genetic diversity for resistance to pathogens, which makes the use of resistant cultivars the most economic and efficient form of disease control (Balmer \& Pereira, 1987; Silva, 2001). It has been reported that resistance to $P$. maydis is a quantitative trait, and the additive gene action has greater importance for character inheritance, while the dominant gene action has a less important expression (Carson et al., 1996; Pegoraro et al., 2000; Carson, 2001).

The application of concepts of heterosis, general and specific combining abilities (GCA and SCA, respectively) has been utilized for grain-producing crop breeding; GCA is relatively more important than SCA for nonselected endogamic lines, while the opposite is true for previously-selected lines (Sprague \& Tatum, 1942; Hallauer \& Miranda Filho, 1988; Nass et al., 2000). These concepts are useful both for the characterization of lines in crosses and for establishing heterotic standards between maize populations (Hallauer \& Miranda Filho, 1988; Beck et al., 1990; Crossa et al., 1990; Han et al., 1991; Vasal et al., 1992), and in maize disease genetic resistance studies (Nelson \& Scott, 1973; Lim \& White, 1978; Callaway et al., 1990). To provide support for the development of varieties and hybrids resistant to $P$. maydis, the present work aimed at evaluating the heterotic effects, the interaction of those effects with the environment, and the combination ability of a group of endogamous maize lines, adapted to the conditions of South and Central regions of Brazil, on the resistance to P. maydis, in order to select superior hybrid combinations with a high degree of resistance to this pathogen.

\section{MATERIAL AND METHODS}

The nine lines utilized in this work were obtained by at least seven successive self-fertilizations (Table 1). DAS41 and DAS21 are early lines, with semi-flint, orangish kernels, from the Suwan DMR population, and are considered, respectively, resistant and susceptible to P. maydis. The Suwan DMR population was developed in Thailand from a selection of tropical flint materials from the Caribbean and from Tuxpeño dent materials, and was released as Thai Composite 1 after several recurring selection cycles. Two sources of resistance to Peronosclerospora sorghi from the Philippines (DMR 1 and DMR 5) were incorporated into this material, resulting in the CMS 05 population, which is being utilized by Centro Nacional de Pesquisa de Milho e Sorgo (CNPMS) of Empresa Brasileira de Pesquisa Agropecuária (EMBRAPA). DAS42 and DAS56, susceptible to $P$. maydis, are early lines, with flint, orangish kernels, originated from the Suwan-3 population. This population was obtained by means of recurring selection from the Suwan1 population.

Lines DAS86, DAS72, and DAS2 are resistant to moderately resistant to this pathogen, early, with semiflint, orangish kernels, from the same restricted-genetic-base synthetic, group of lines obtained from the Amarillo Dentado population and from endogamous lines obtained from a tropical flint population of the Caribbean. Both populations are widely utilized in public and private breeding programs in Asia. The resistant line DAS95 is early, with flint, orangish kernels, originating from a synthetic group of lines from flint tropical

Table 1 - Lines evaluated for reactions to Phaeosphaeria leaf spot and their sources.

\begin{tabular}{lcc}
\hline Line & Source & Reaction to P. maydis \\
\hline DAS95 & Tropical Flint Synthetic & Resistant \\
DAS41 & Suwan DMR & Resistant \\
DAS86 & Amarillo Dentado/ Caribbean Flint & Resistant \\
DAS72 & Amarillo Dentado/ Caribbean Flint & Moderately Resistant \\
DAS2 & Amarillo Dentado/ Caribbean Flint & Moderately Resistant \\
DAS56 & Suwan 3 & Moderately Resistant \\
DAS21 & Suwan DMR/ Caribbean Flint & Moderately Susceptible \\
DAS42 & Suwan 3 & Susceptible \\
DAS93 & BSSS * & Susceptible \\
\hline
\end{tabular}

* BSSS is an abbreviation for Iowa Stiff Stalk Synthetic. 
materials with an orangish coloration. Finally, line DAS93 is super-early, with dent, yellowish kernels, originated from temperate materials derived from the BSSS synthetic (Iowa Stiff Stalk Synthetic) and formed from 16 lines, with at least seven of them derived from the Reid Yellow Dent population. This synthetic is widely utilized in breeding programs in the United States, Europe and Argentina.

Multiplication of the endogamous lines and the obtainment of $\mathrm{F}_{1}$ generations were performed during the 1997/98 cropping season, in Cravinhos - SP. The thirty six simple hybrids were obtained from diallelic crosses between the nine lines.

Evaluations were performed during the 1999/ 2000 cropping season in three locations: Cravinhos, Northeast São Paulo State (2120'25' S, 47043'46"W; altitude $820 \mathrm{~m}$ ), Iraí de Minas, Minas Gerais State $\left(18^{\circ} 59^{\prime} 02^{\prime \prime} \mathrm{S}, 4^{\circ} 27^{\prime} 41^{\prime \prime} \mathrm{W}\right.$; altitude $\left.980 \mathrm{~m}\right)$ and Taquarituba, Southwestern São Paulo State (2331'59"'S, $49^{\circ} 14^{\prime} 40^{\prime \prime} \mathrm{W}$; latitude $730 \mathrm{~m}$ ). The cultural practices adopted in the trials were the same as those adopted by growers of the specific regions.

Thirty days prior to planting, a border hybrid susceptible to Phaeosphaeria maydis was planted and inoculated with pycnidiospores from Cravinhos, Taquarituba, and Iraí de Minas. The pycnidiospores were obtained by washing infected leaves with distilled water; the leaves had been previously placed inside plastic bags, with the interior moistened with water, and left in the shade for 48 hours. Inoculation consisted in spraying $5 \mathrm{~mL}$ of the spore suspension into the whorl of each plant, adjusted to a concentration of $1 \times 10^{3}$ pycnidiospores $\mathrm{mL}^{-1}$ distilled water, which had been added of one droplet of mineral oil at viscosity 80 per $1000 \mathrm{~mL}$. Inoculations were performed 30 and 45 days after planting, corresponding, respectively, to growth stages 3 and 5, according to the methodology described by Hanway (1966). The experimental area was irrigated one hour before inoculation, in the afternoon. Calibration of the inoculum was performed with a hemocytometer.

Resistance to Phaeosphaeria leaf spot was evaluated in all plants all trials by scoring the severity of the disease in the entire plant (PI) and in the leaf located below the insertion point of the main ear (AFA), at phenological stage 7, according to Fancelli \& Silveira Neto (1997). The evaluation of the disease in the entire plant was performed by attributing nine severity ratings with the use of a diagramatic scale, in which $1=0 \%, 2=0$ to $1 \%, 3=1$ to $2.5 \%, 4=2.5$ to $5 \%, 5=5$ to $10 \%, 6=10$ to $25 \%, 7=25$ to $50 \%, 8=50$ to $75 \%, 9=>75 \%$ of affected leaf area in the plant. The severity of the disease in the leaf positioned below the main ear was evaluated with the diagrammatic scale containing the values: $0 ; 0.1 \%$; $0.3 \% ; 0.7 \% ; 2 \% ; 5 \% ; 12 \% ; 27 \%$ and $>50 \%$ of affected leaf area.
For ANOVA purpose, data expressed as severity ratings and percentages were transformed to square root and arcsine of square root, respectively. The experimental design consisted of randomized blocks with three replicates in each environment. Plots were represented by 5 $\mathrm{m}$-long rows, spaced at $0.80 \mathrm{~m}$, with 25 plants per plot; plants were spaced $20 \mathrm{~cm}$, with a population stand of 62,500 plants $\mathrm{ha}^{-1}$. Within each replicate, the usable plots containing lines were surrounded by a resistant line border, while the usable plots containing hybrids were surrounded by a simple resistant hybrid border. The ANOVA for reactions to Phaeosphaeria leaf spot were performed according to the Gardner \& Eberhart (1966) method and to method 4, model I, by Griffing (1956).

\section{RESULTS AND DISCUSSION}

Heterosis and combination ability estimates in crosses between lines allow not only to determine the contribution of each line toward resistance, but also to identify hybrid combinations of agronomic interest. The average disease severity in the entire plant (PI) and for leaf area affected in the leaf, located below the insertion point of the $1^{\text {st }}$ ear (AFA), for the Taquarituba, Cravinhos and Iraí de Minas environments, ranged from 1.27 to 7.90 for PI (Table 2) and from 0.12 to $50.00 \%$ for AFA (Table 3). The greatest mean disease severity values were observed in the Iraí de Minas environment for both evaluation methods, followed by Cravinhos and Taquarituba, which presented smaller severity value means.

The hybrid combinations with the greatest level of resistance were obtained from crosses of line DAS95 with lines DAS41, DAS86, DAS72, and DAS2 in the three locations: Taquarituba, Cravinhos and Iraí de Minas (Tables 2 and 3). Considering the mean for the three locations and for the two evaluation methods, the studies involving endogamous lines DAS95, DAS41, and DAS86 evidenced the smallest severity values (data not shown). However, hybrids DAS42 $\times$ DAS93 and DAS $21 \times$ DAS93 were the most susceptible. The presence of total heterosis for resistance was found in both crosses between resistant lines and between susceptible lines. (Tables 2 and 3).

The diallelic analysis by the Gardner \& Eberhart (1966) method revealed variation between lines for resistance evaluated by the two methods (Table 4). The mean squares for total heterosis, mean heterosis, line heterosis and specific heterosis were not significant for both evaluation methods. Severity evaluated for the entire plant (PI) should be used as evaluation method, because of the little differences between methods, as well as to the absence of a $G \times E$ interaction, because it presented smaller coefficient of variation values in the analysis of variance, and because it is more practical to be used. The utilization of a single variable reduces the amount of work involved in data collection. 
The Suwan DMR population has been developed in Thailand from a selection of tropical flint materials from the Caribbean and from Tuxpeño dent materials, which was released as Thai Composite 1 . This population has demonstrated to be a good source for the extraction of lines resistant to Phaeosphaeria leaf spot, has wide genetic variability for resistance to the disease, good GCA for agronomic characters and productivity, and has great adaptation ability to tropical and subtropical environments. The lines obtained from the Amarillo Dentado/ Caribbean Flint materials also presented good level of resistance, good agronomic characters and were adapted to tropical environments.

By the Griffing method, the combination ability determination in different environments produced highly significant values $(P<0.01)$ for the A.F.A method, but were non-significant by the PI evaluation method for environments (E), and showed highly significant effects $(P<0.01)$ for GCA and GCA $\times$ E evaluated through both methods. For SCA and SCA $\times$ E the effects were non-sig- nificant for both evaluation methods (Table 5). The significances of mean square effects for GCA $\times \mathrm{E}$ suggest that it is necessary to select parental lines to obtain hybrids in specific environments. Choosing parents based on the mean for the GCA effects can be done if there is interest in simple hybrids adapted to all environments. The GCA $\times \mathrm{E}$ interaction, however, indicated that the greatest GCA values were not the same for all environments.

Studies aimed at resistance to diseases and grain productivity have shown that GCA and SCA can interact with the environment (Rojas \& Sprague, 1952; Matzinger et al., 1959; Parodas \& Hayes, 1971; Nelson $\&$ Scott, 1973). In tropical regions, these interactions are particularly interesting, since there is expressive variation between locations, even when they are not far apart from each other. In temperate regions, under variations in altitude, greater variations in day length and temperature can be observed than in tropical regions, which makes the work of the breeder more intense and more challenging (Miranda Filho, 1985; Paterniani, 1990).

Table 2 - Reactions of nine endogamous lines and 36 crosses in relation to Phaeosphaeria maydis, in three locations, evaluated by a severity scale of the disease in the entire plant.

\begin{tabular}{|c|c|c|c|c|c|c|c|c|c|}
\hline \multicolumn{10}{|c|}{ Line } \\
\hline Taquarituba & DAS95 & DAS41 & DAS86 & DAS72 & DAS2 & DAS56 & DAS21 & DAS42 & DAS93 \\
\hline DAS95 & 1.45 & 1.27 & 1.99 & 1.83 & 3.03 & 3.28 & 3.58 & 3.20 & 3.72 \\
\hline DAS 41 & & 1.91 & 3.03 & 2.78 & 4.78 & 3.92 & 4.50 & 5.69 & 5.93 \\
\hline DAS86 & & & 2.83 & 3.57 & 3.82 & 3.73 & 4.70 & 5.52 & 4.45 \\
\hline DAS72 & & & & 3.80 & 3.48 & 3.77 & 4.82 & 4.88 & 5.17 \\
\hline DAS2 & & & & & 4.72 & 4.93 & 5.88 & 5.85 & 5.93 \\
\hline DAS56 & & & & & & 4.58 & 5.50 & 6.08 & 5.57 \\
\hline DAS21 & & & & & & & 6.08 & 6.53 & 6.95 \\
\hline DAS42 & & & & & & & & 6.78 & 6.62 \\
\hline DAS93 & & & & & & & & & 7.47 \\
\hline \multicolumn{10}{|l|}{ Cravinhos } \\
\hline DAS95 & 1.72 & 1.78 & 1.77 & 1.83 & 2.75 & 3.22 & 3.28 & 3.30 & 3.58 \\
\hline DAS41 & & 2.25 & 3.05 & 3.07 & 5.35 & 4.77 & 5.62 & 6.08 & 4.87 \\
\hline DAS 86 & & & 2.93 & 4.05 & 4.03 & 4.05 & 4.80 & 5.83 & 4.70 \\
\hline DAS72 & & & & 4.30 & 3.73 & 4.28 & 4.68 & 5.20 & 4.65 \\
\hline DAS2 & & & & & 5.03 & 5.68 & 6.22 & 5.98 & 5.53 \\
\hline DAS56 & & & & & & 5.97 & 5.63 & 6.17 & 6.45 \\
\hline DAS21 & & & & & & & 6.23 & 6.52 & 6.35 \\
\hline DAS42 & & & & & & & & 6.62 & 6.50 \\
\hline DAS93 & & & & & & & & & 6.97 \\
\hline \multicolumn{10}{|c|}{ Iraí de Minas } \\
\hline DAS95 & 1.48 & 2.02 & 2.00 & 1.98 & 3.08 & 3.55 & 3.85 & 3.70 & 5.42 \\
\hline DAS41 & & 3.48 & 3.37 & 3.52 & 5.40 & 6.07 & 5.93 & 6.68 & 6.82 \\
\hline DAS 86 & & & 3.10 & 5.12 & 4.47 & 5.05 & 4.72 & 6.43 & 6.77 \\
\hline DAS72 & & & & 5.45 & 4.10 & 4.88 & 5.77 & 6.52 & 6.47 \\
\hline DAS2 & & & & & 6.48 & 6.32 & 6.43 & 6.98 & 6.92 \\
\hline DAS56 & & & & & & 6.88 & 6.00 & 6.85 & 7.07 \\
\hline DAS21 & & & & & & & 6.50 & 6.90 & 7.12 \\
\hline DAS42 & & & & & & & & 7.23 & 6.93 \\
\hline DAS93 & & & & & & & & & 7.90 \\
\hline
\end{tabular}

Sci. Agric. (Piracicaba, Braz.), v.61, n.1, p.36-42, Jan./Fev. 2004 
Table 3 - Reactions of nine endogamous lines and 36 crosses in relation to Phaeosphaeria maydis, in three locations, evaluated by percentage of affected leaf area.

\begin{tabular}{|c|c|c|c|c|c|c|c|c|c|}
\hline \multicolumn{10}{|c|}{ Line } \\
\hline Taquarituba & DAS95 & DAS41 & DAS86 & DAS72 & DAS2 & DAS56 & DAS21 & DAS42 & DAS93 \\
\hline DAS95 & 0.49 & 0.12 & 1.01 & 1.11 & 0.90 & 3.22 & 6.02 & 2.08 & 4.92 \\
\hline DAS41 & & 0.65 & 1.18 & 2.38 & 8.03 & 4.85 & 5.49 & 18.99 & 25.27 \\
\hline DAS 86 & & & 2.26 & 3.19 & 6.56 & 6.34 & 8.25 & 14.97 & 7.65 \\
\hline DAS72 & & & & 3.73 & 3.77 & 3.89 & 10.80 & 9.27 & 9.82 \\
\hline DAS2 & & & & & 4.99 & 6.87 & 17.55 & 18.07 & 15.75 \\
\hline DAS56 & & & & & & 5.15 & 18.28 & 20.60 & 19.35 \\
\hline DAS21 & & & & & & & 24.90 & 35.40 & 40.07 \\
\hline DAS42 & & & & & & & & 38.83 & 34.72 \\
\hline DAS93 & & & & & & & & & 48.47 \\
\hline \multicolumn{10}{|l|}{ Cravinhos } \\
\hline DAS95 & 0.89 & 0.54 & 0.872 & 1.12 & 2.48 & 2.33 & 3.25 & 3.26 & 4.21 \\
\hline DAS41 & & 1.15 & 2.27 & 1.59 & 18.90 & 5.24 & 17.80 & 23.28 & 21.92 \\
\hline DAS86 & & & 3.22 & 5.43 & 5.61 & 7.09 & 11.05 & 15.33 & 11.30 \\
\hline DAS72 & & & & 5.00 & 5.27 & 5.74 & 9.70 & 14.86 & 8.33 \\
\hline DAS2 & & & & & 7.17 & 22.19 & 27.45 & 26.50 & 22.53 \\
\hline DAS56 & & & & & & 23.90 & 16.88 & 20.36 & 28.48 \\
\hline DAS21 & & & & & & & 26.93 & 30.53 & 40.72 \\
\hline DAS42 & & & & & & & & 42.62 & 29.18 \\
\hline DAS93 & & & & & & & & & 41.95 \\
\hline \multicolumn{10}{|c|}{ Iraí de Minas } \\
\hline DAS95 & 0.46 & 0.95 & 1.09 & 0.79 & 3.48 & 4.20 & 5.63 & 5.49 & 10.55 \\
\hline DAS41 & & 5.85 & 6.82 & 5.25 & 12.78 & 10.01 & 18.25 & 31.25 & 30.97 \\
\hline DAS86 & & & 5.72 & 9.67 & 9.57 & 8.32 & 14.96 & 35.18 & 29.91 \\
\hline DAS72 & & & & 19.42 & 4.72 & 11.13 & 22.16 & 27.22 & 23.20 \\
\hline DAS2 & & & & & 35.87 & 26.82 & 30.88 & 43.10 & 32.13 \\
\hline DAS56 & & & & & & 38.63 & 24.05 & 38.25 & 41.83 \\
\hline DAS2 1 & & & & & & & 34.58 & 35.45 & 41.18 \\
\hline DAS42 & & & & & & & & 47.26 & 34.68 \\
\hline DAS93 & & & & & & & & & 50.00 \\
\hline
\end{tabular}

Table 4 - Joint variance analysis by the Gardner \& Eberhart method for severity of the disease in the entire plant (PI) and percentage of affected leaf area (AFA) by P. maydis for nine endogamous lines and 36 diallelic crosses evaluated in three locations.

\begin{tabular}{|c|c|c|c|}
\hline Source of Variation & & Mean square & \\
\hline & D.F. & PI & $\%$ A. F. A. \\
\hline Environments (E) & 2 & $0.169 \mathrm{~ns}$ & $0.083 * *$ \\
\hline Genotypes (corrected) (G) & 44 & $0.150 * *$ & $0.034 * *$ \\
\hline Lines & 8 & $0.758 * *$ & $0.171 * *$ \\
\hline Heterosis & 36 & $0.014 \mathrm{~ns}$ & $0.004 \mathrm{~ns}$ \\
\hline Mean Heterosis & 1 & $0.003 \mathrm{~ns}$ & $0.013 \mathrm{~ns}$ \\
\hline Line Heterosis & 8 & $0.023 \mathrm{~ns}$ & $0.005 \mathrm{~ns}$ \\
\hline Specific Heterosis & 27 & $0.012 \mathrm{~ns}$ & $0.003 \mathrm{~ns}$ \\
\hline GCA & 8 & $37.682 * *$ & $1.107 * *$ \\
\hline $\mathrm{G} \times \mathrm{E}$ Interaction & 88 & $0.003 \mathrm{~ns}$ & $0.001 \mathrm{n} . \mathrm{s}$ \\
\hline Error & 270 & 0.108 & 0.013 \\
\hline MS(GCA)/MS(SCA) & & 3260.900 & 368.895 \\
\hline $\mathrm{CV} \%$ & & 15.272 & 31.138 \\
\hline
\end{tabular}

n.s, ${ }^{*}, * *$-Significance levels by $\mathrm{F}$ test: non-significant and significant at $P<0.05$ and $P<0.01$, respectively.

Sci. Agric. (Piracicaba, Braz.), v.61, n.1, p.36-42, Jan./Fev. 2004 
The GCA effects were more important than SCA, as judged from their mean square values. Therefore, the genetic additive effects are, for the most part, responsible for the source of variation for resistance to this disease, in this set of lines, for both evaluation methodologies or for both characters (PI and AFA) (Table 5). Consequently, emphasis should be placed on the mean performance of the line in hybrid combinations during selection, for the breeding program to advance toward resistance to Phaeosphaeria leaf spot. Even though not significant in the analysis of variance, SCA presented some prominent combinations, such as the DAS95 $\times$ DAS41 cross, with a $\left(s_{i j}\right)=-0.206$ and mean for the three locations $=1.69$, for the PI character. Significant specific combinations were also found, however at a lower significance level. SCA was significant, at a lower significance level, but it is important with respect to the expression of resistance, even if this is true for only some of the crosses. Its effects, whether positive or negative, should be consistent in the environments, given the non-significance of the SCA $\times \mathrm{E}$ term.

The means for the GCA estimate, for the three locations and for the nine lines evaluated by the two methods, are presented in Table 6. The orientations of the genetic effects for resistance to the disease were negative in several cases because resistant plants presented lower severity values. Approximately half of the parental lines, evaluated by the two methods, had negative GCA effects, indicating that, on average, these parents contributed to increased resistance of the crosses. Greater negative GCA effects were observed on line DAS95 and greater positive GCA effects were observed on lines DAS93 and DAS42, for both evaluation methods. Highly significant and negative GCA effects were found on lines DAS95, DAS41, DAS86, and DAS72, for both evaluation methods and for crosses between resistant lines. Positive GCA values indicate that it is pointless to utilize parents in crosses.

Table 5 - Mean squares by the Griffing method IV, of the general combination (GCA) and specific combination abilities (SCA), and interactions with locations, for severity in the entire plant (PI), and percentage of leaf area affected (AFA) by Phaeosphaeria maydis for nine endogamous lines and 36 diallelic crosses evaluated in three locations.

\begin{tabular}{lrcc}
\hline Source of Variation & \multicolumn{3}{c}{ Mean square } \\
\hline & D.F. & \multicolumn{1}{c}{ PI } & A. F. A. \% \\
Environments (E) & 2 & $0.169 \mathrm{~ns}$ & $0.083 * *$ \\
GCA & 8 & $37.682 * *$ & $1.107 * *$ \\
SCA & 27 & $0.012 \mathrm{~ns}$ & $0.003 \mathrm{~ns}$ \\
GCA $\times$ E & 8 & $75.556 *$ & $2.277 * *$ \\
SCA $\times$ E & 27 & $0.035 \mathrm{~ns}$ & $0.011 \mathrm{~ns}$ \\
G $\times$ E Interaction & 88 & $0.002 \mathrm{~ns}$ & $0.001 \mathrm{~ns}$ \\
Combined error & 270 & 0.108 & 0.013 \\
\hline CV \% & & 15.272 & 31.138 \\
\hline
\end{tabular}

$\mathrm{ns},{ }^{*}, * *$-Significance levels by $\mathrm{F}$ test: non-significant, significant at $P<0.05$ and $P<0.01$, respectively.
Line DAS95 shows potential for utilization in breeding programs, since an increase in resistance was observed in all crosses with other lines. Line DAS41, on the other hand, can be utilized in specific crosses for the synthesis of hybrids resistant to Phaeosphaeria leaf spot.

The highest negative and positive SCA values for severity in the entire plant (PI) were observed for crosses DAS95 $\times$ DAS41 and DAS86 $\times$ DAS72, respectively (Table 7). For the AFA evaluation, the highest negative and positive SCA effect was observed for crosses of lines DAS95 $\times$ DAS42 and DAS41 $\times$ DAS93, respectively; this highlights the magnitude of the SCA effects in hybrid combinations for resistance to this disease, which are combinations that can be successfully utilized for its genetic control.

The absence, or small magnitude, of non-additive genetic effects for resistance to a number of diseases has been reported by several authors (Hughes \& Hooker, 1971; Lim \& Hooker, 1976; Kappelman Jr. \& Thompson, 1981). The smaller expression of the non-additive genetic effects for the characters under evaluation should be attributed to the absence of deleterious genes that cause endogamic depression, even though these effects, on the average, have smaller importance than additive effects; however, in specific hybrid combinations, they can be of paramount importance (Hallauer \& Miranda Filho, 1988). Results herein presented concerning the genetic control of resistance to the disease as additivity or dominance, are restricted to this group of materials and serve as a reference for projects dealing with fixed groups of lines.

Table 6 - Mean estimates of general combination ability (gi) for the scale of severity of the disease in the entire plant (PI) transformed to square root, and percentage of leaf area affected (AFA) transformed to arcsine of the square root of percentage, of reactions to Phaeosphaeria maydis, according to the Gardner and Ebehart method, analysis II, associated to method 2 by Griffing (1956) model I, for nine lines in three locations.

\begin{tabular}{|c|c|c|}
\hline & \multicolumn{2}{|c|}{ General combination ability $\left(\mathrm{g}_{\mathrm{i}}\right)$} \\
\hline $\begin{array}{l}\text { Endogamous } \\
\text { lines }\end{array}$ & $\begin{array}{c}\text { Severity of the disease (PI) } \\
\text { (Rating) }\end{array}$ & A.F.A. $\%$ \\
\hline DAS95 & -0.553 & -0.227 \\
\hline DAS41 & -0.104 & -0.055 \\
\hline DAS 86 & -0.150 & -0.081 \\
\hline DAS72 & -0.160 & -0.098 \\
\hline DAS2 & 0.077 & 0.025 \\
\hline DAS56 & 0.104 & 0.017 \\
\hline DAS 21 & 0.206 & 0.109 \\
\hline DAS42 & 0.292 & 0.155 \\
\hline DAS93 & 0.288 & 0.156 \\
\hline $\begin{array}{l}\text { Standard } \\
\text { deviation }\left(g_{\mathrm{i}}\right)\end{array}$ & 0.097 & 0.046 \\
\hline $\begin{array}{l}\text { Standard } \\
\text { deviation }\left(g_{\mathrm{i}}-\mathrm{g}_{\mathrm{j}}\right)\end{array}$ & 0.146 & 0.069 \\
\hline
\end{tabular}


Table 7 - Mean estimates of specific combination ability $\left(\mathrm{s}_{\mathrm{ij}}\right)$ for severity of the disease in the entire plant (PI), (above diagonal), and percentage of affected leaf area (AFA), (below diagonal), by P. maydis, according to the Gardner and Ebehart method, analysis II, associated to method 2 by Griffing (1956) model I, for 36 diallelic crosses in three locations.

\begin{tabular}{lccccccccc}
\hline & DAS95 & DAS41 & DAS86 & DAS72 & DAS2 & DAS56 & DAS21 & DAS42 & DAS93 \\
\hline DAS95 & - & $-0.206^{\mathrm{a}}$ & -0.069 & -0.072 & 0.039 & 0.123 & 0.080 & -0.052 & 0.158 \\
DAS41 & $-0.004^{\mathrm{b}}$ & - & -0.128 & -0.127 & 0.144 & 0.053 & 0.051 & 0.136 & 0.077 \\
DAS86 & 0.053 & -0.045 & - & 0.207 & -0.059 & -0.047 & -0.036 & 0.135 & -0.002 \\
DAS72 & 0.070 & -0.032 & 0.067 & - & -0.132 & -0.027 & 0.052 & 0.060 & 0.039 \\
DAS2 & -0.007 & 0.041 & -0.029 & -0.068 & - & 0.035 & 0.046 & -0.023 & -0.049 \\
DAS56 & 0.033 & -0.060 & -0.021 & -0.015 & 0.033 & - & -0.076 & -0.030 & -0.029 \\
DAS21 & -0.017 & -0.038 & -0.043 & 0.014 & 0.035 & -0.023 & - & -0.075 & -0.042 \\
DAS42 & -0.097 & 0.059 & 0.049 & 0.006 & 0.030 & 0.008 & 0.001 & - & -0.151 \\
DAS93 & -0.031 & 0.079 & -0.031 & -0.042 & -0.035 & 0.045 & 0.071 & -0.056 & - \\
\hline
\end{tabular}

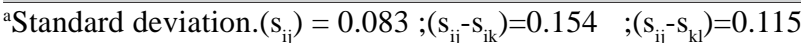

${ }^{\mathrm{b} S t a n d a r d ~ d e v i a t i o n .}\left(\mathrm{s}_{\mathrm{ij}}\right)=0.039 ;\left(\mathrm{s}_{\mathrm{ij}}-\mathrm{s}_{\mathrm{ik}}\right)=0.073 ;\left(\mathrm{s}_{\mathrm{ij}}-\mathrm{s}_{\mathrm{kl}}\right)=0.054$

\section{REFERENCES}

BALMER, E.; PEREIRA, O.A.P. Doenças do milho. In: PATERNIANI, E.; VIEGAS, G.P. (Ed.) Melhoramento e produção de milho. 2.ed. Campinas: Fundação Cargill, 1987. v.2, cap.14, p.595-634.

BECK, D.L.; VASAL, S.K.; CROSSA, J. Heterosis and combining ability of CIMMYT'S tropical early and intermediate maturity maize (Zea mays L.) germplasm. Maydica, v.35, p.279-285, 1990.

CALLAWAY, M.B.; SMITH, M.E.; COFFMAN, W.R. Diallel analysis of resistance to anthracnose stalk rot in maize inbreds. Crop Science, v.30, p.335-337, 1990.

CARSON, M.L. Inheritance of resistance to Phaeosphaeria leaf spot of maize. Plant Disease, v.85, p.798-800, 2001

CARSON, M.L.; STUBER, C.W.; SENIOR, M.L. Identification of quantitative trait loci (QTLs) for resistance to two foliar diseases in a mapping population of recombinant inbred (RI) lines of maize. Phytopathology, v.86, p.59, 1996.

CROSSA, J.; VASAL, S.K.; BECK, D.L. Combining ability estimates of CIMMYT's tropical late yellow maize germplasm. Maydica, v.35, p.273$278,1990$.

FANCELLI, L.C.; SILVEIRA NETO, A. Aspectos fisiológicos da cultura do milho. In: SIMPÓSIO SOBRE A CULTURA DO MILHO, Piracicaba, 1997. Piracicaba: USP/ESALQ, 1997. p.60-67.

FANTIN, G.M.; BALMER, E. Método de inoculação e evolução de sintomas da mancha foliar de Phaeosphaeria maydis em milho. Summa Phytopathologica, v.23, p.64-65, 1997.

GARDNER, C.O.; EBERHART, S.A. Analysis and interpretation of the variety cross diallel and related populations. Biometrics, v.22, p.439452, 1966.

GRIFFING, B. Concept of general and specific combining ability in relation to diallel crossing systems. Australian Journal of Biological Science, v.9, p.463-493, 1956.

HALLAUER, A.R.; MIRANDA FILHO, J.B. Quantitative genetics in maize breeding. Ames: Iowa State University Press, 1988. 375p.

HAN, G.C.; VASAL, S.K.; BECK, D.L.; ELIAS, E. Combining ability of inbred lines derived from CIMMYT maize (Zea mays L) germplasm. Maydica, v.36, p.57-64, 1991.

HANWAY, A.L. How a corn plant develops. Iowa: Iowa Agricultural Experiment Station, 1966. 15p. (Special Report, 48).

HUGHES, G.R.; HOOKER, A.L. Gene action conditioning resistance to northern leaf blight in maize. Crop Science, v.11, p.180-184, 1971

KAPPELMAN JR., A.J.; THOMPSON, D.L. Inheritance of resistance to Diplodia stalk rot in corn. Crop Science, v.6, p.288-290, 1981.

LIM, S.M.; HOOKER, A.L. Estimates if combining ability for resistence to Helminthosporium maydis race $\mathrm{O}$ in a maize population. Maydica, v.21, p.121-128, 1976.

LIM, S.M.; WHITE, D.G. Estimates of heterosis and combining ability for resistance of maize to Colletotrichum graminicola. Phytopathology, v.68, p.1336-1342, 1978.

Sci. Agric. (Piracicaba, Braz.), v.61, n.1, p.36-42, Jan./Fev. 2004
MATZINGER, D.F.; SPRAGUE, G.F.; COCKERHAM, C.C. Diallel cross of maize in experiments repeated over locations and years. Agronomy Journal, v.51, p.346-350, 1959.

MIRANDA FILHO, J.B. Breeding methodologies for tropical maize. In: BRANDOLINI, A.; SALAMINI, F. (Ed.) Breeding strategies for maize production improvement in the tropics. Firenze: FAO; Instituto Agronomico per l'Oltremare, 1985. cap.1, p.169-185.

NASS, L.L.; LIMA, M.; VENCOVSKY, R.; GALLO, P.B. Combining ability of maize inbred lines evaluated in three environments in Brazil. Scientia Agricola, v.57, p.129-134, 2000.

NELSON, L.R.; SCOTT, G.E. Diallel analysis of resistance of corn (Zea mays L.) to Corn Stunt. Crop Science, v.13, p.162-164, 1973.

PACCOLA-MEIRELLES, L.D.; MEIRELLES, W.F.; CERVELATTI, E.P.; MAKI, C.S; CASELA, C.R.; FERNANDES, F.T.; FERREIRA, A.S. Caracterização morfológica das lesões por Phaeosphaeria e avaliação do estágio sexuado e assexuado do patógeno em híbridos de milho. In: CONGRESSO NACIONAL DE MILHO E SORGO, 22, Recife, 1998. Resumos. Recife, 1998. p.173.

PACCOLA-MEIRELLES, L.D.; FERREIRA, A.S.; MEIRELLES, W.F.; MARRIEL, I.E.; CASELA, C.R. Detection of a bacterium associated with a leaf spot disease of maize in Brazil. Journal of Phytopathology, v.149, p.275-279, 2001

PARODAS, R.S.; HAYES, J.D. An investigation of genotype-environment interactions for rate of ear emergence in spring barley. Heredity, v.26, p.157-175, 1971.

PATERNIANI, E. Maize breeding in the tropics. CRC Critical Review in Plant Science, v.9, p.125-154, 1990.

PEGORARO, D.G.; BARBOSA NETO, J.F.; DAL SOGLIO, F.K.; VACARO, E.; NUSS, C.; CONCEIÇÃO, L.D.H. Genética da resistência à mancha foliar de feosféria em milho. In: REUNIÃO TÉCNICA ANUAL DO MILHO, 45., Pelotas, 2000. Pelotas: EMBRAPA, 2000, p. 232-237.

RANE, M.S.; PAYAK, M. M.; RENFRO, B.L.A. Phaeosphaeria Leaf spot of maize. Indian Phytopathology Society Bulletin, v.3, p.7-10, 1965.

ROJAS, B.A.; SPRAGUE, G.F. A comparision of variance components in corn yield trials: III. General and specific combining ability and their interaction with locations and years. Agronomy Journal, v.44, p.462-466, 1952.

SILVA, H.P. Incidência de doenças fúngicas na "safrinha". In: SEMINÁRIO SOBRE A CULTURA DO MILHO "SAFRINHA", 4., Campinas, 1997. Campinas: IAC, CDV, 1997.

SILVA, H.P. Análise genética da resistência a Puccinia polysora Underw em milho (Zea mays L). Piracicaba: USP/ESALQ, 2001. 87p. (Tese Doutorado)

SPRAGUE, G.F.; TATUM, L.A. General vs. specific combining ability in single crosses of corn. Journal of the American Society of Agronomy, v.34, p.923-932, 1942.

VASAL, S.K.; SRINIVASAN, G.; HAN, G.C.; GONZALES, C.F. Heterotic patterns of eighty-eight white subtropical CIMMYT maize lines. Maydica, v.37, p.319-327, 1992.

Received May 14, 2002

Accepted October 29, 2003 